\title{
Die historiese ondersoek na Jesus van Nasaret in perspektief
}

Andries van Aarde

Universiteit van Pretoria

\begin{abstract}
Historical Jesus research in perspective

The quest for the historical Jesus has been a vitally central topic in New Testament scholarship. The article aims at explaining to non-scholars some of the premisses and methods of this historical critical enterprise. Issues concerning the question about who the 'real' Jesus is, the relevance of the quest seen from the angles of both the church and the university, the nature of historical inquiry and criteria applied in historical Jesus research, and the resurrection and the virginal conception are discussed. The article is written from the assumption that the Jesus who matters is both the Jesus of history and the Jesus of faith. It is shown that historical investigation reveals trajectories respectively with regard to reports about the resurrection and the virgininal conception of Jesus in the New Testament and with regard to creedal statements.
\end{abstract}

\section{DIE 'WERKLIKE JESUS'?}

Jesus, die seun van Maria, is gebore in die tyd toe die baster-Jood, Herodes die Grote, deur die Romeinse senaat as 'koning van die Jode' in Jerusalem aangestel is. Dit was die tyd toe Augustus, die aangenome seun van Julius Caesar, die eerste keiser van die Romeinse Ryk was. Jesus, die Galileër, se bykans totale openbare optrede moet gesien word teen die agtergrond van die militêre regime van Herodes Antipas, seun van die toe reeds oorlede vasalkoning, Herodes die Grote. Na slegs enkele jare van openbare optrede is Jesus op grond van sy provokasie op die tempelplein in Jerusalem, toe Hy die tafels van geldwisselaars omgegooi het, gevang en deur die soldate van die Romeinse goewerneur in Jerusalem, Pontius Pilatus, gekruisig asof Hy 'n krimineel was. Sy optrede op die tempelplein was niks anders nie as 'n skokkende simboliese handeling, verwysende na sy totale lewe wat implisiet en eksplisiet getuig het van

* Voordrag gelewer voor die Kerk/Universiteit Gespreksgroep, Randse Afrikaanse Universiteit, 20 Mei 1996. 
kritiek teen die reinheidsideologie van die tempelowerhede. Sy hele lewe sedert geboorte konsentreer in die skande van sy kruisdood - 'n 'nobody' wie se lewe volgens die konvensies van die Judese tempelideologie met één woord opgesom kan word: 'skande', 'aanstoot'!

Ons weet, histories gesien, dat Jesus van die Galilese dorpie Nasaret kom, dat Hy ongetroud was, 'n seun van Maria, miskien 'n skrynwerker, definitief 'n persoon wat in spanning met sy familie gestaan het. 'n Vaderfiguur het nie 'n rol in sy lewe gespeel nie. Hy het God sy Vader genoem. Hy is as 'sondaar' geëtiketteer. Juis as 'sondaar' is Hy deur Johannes die Doper gedoop, 'n simboliese handeling wat wou sê dat 'sondaars' vergifnis van God kan ontvang buite die strukture van die tempel om. Hoewel sy hele lewe teen die agtergrond van die visie van Johannes die Doper, selfs ná die Doper se teregstelling deur Herodes Antipas, verstaan moet word, het Hy sy eie pad met eie dissipels naas die Doperkring begin loop en op sekere punte sterk van die Doper verskil. Jesus was byvoorbeeld nie 'n 'bekeringsprediker' soos Johannes die Doper nie. Hy was 'n vriend van 'sondaars', nie van gewese 'sondaars' nie. Sy boodskap was nie, 'bekeer jou, anders tref God se oordeel jou' nie! Aan 'sondaars', ja as 'sondaar', het Hy gesê, en dit voorgeleef, dat God se 'koninkryk' aan die uitgestotenes, die verlore skape van Israel, 'sondaars' waaronder die 'heidene', behoort. Sy gebruikmaking van die metafoor 'koninkryk' was skokkend. Hiermee het Jesus God se teenwoordigheid by die mense uitgebeeld. Die spanningselement in die metafoor 'koninkryk van God' is dat God se omgee vir mense in neerdrukkende omstandighede met behulp van 'n beeld uit die wêreld van die mag van die elites geillustreer word. En dan nog tot die beswil van juis die 'onheilige sondaars' - mense wat volgens die perspektief van die na-ballingskap Jodedom nie by God se 'heiligheid' pas nie en nie in die 'huis van God', die tempel, of in die huise van die sogenaamde 'regverdiges', kon inkom nie.

Jesus kan beskryf word as 'n 'Geesvervulde' persoon, 'n wysheidsleraar en geneser wat sy eie visie en belewenis van 'alternatiewe wysheid' deur middel van veral kernagtige simboliese spreuke, metaforiese vertellings, genesings en eksorsismes begin bekend maak het. Hy het dit in sy eie lewe waar gemaak dat God onbegrensd en direk, en nie deur middel van belangrike menslike middelaarfigure nie, by ondergeskiktes teenwoordig is. 'n Vrou of kind word nie meer slegs indirek deur die familiehoof voor God verteenwoordig nie. God se teenwoordigheid manifesteer reeds híer en nó́ en nie alleen in die apokaliptiese sin van die woord, dáár en later nie. Dit manifesteer as 'n ontferming vir almal wat in die oë van selfgeregverdigdes niks is, niks het en niks jeens God en mens kan vergeld nie. Jesus se genesings het op die resosialisasie van uitgestotenes neergekom. Melaatses en ander 'onreines' is nie uit die gemeenskap, weg 
van God af, uitgestoot nie. Sy genesings en duiweluitdrywings kan as coping-healings tipeer word. Sodoende het Hy die koninkryk van God metafories herdefinieer in terme van 'n nie-hiërargiese, denkbeeldige huishouding waarin al die lede van dié familie op 'n gelyke wyse direkte toegang tot die Vader het en die Vader vir diesulkes wat weet hoe arm hulle voor God is, omgee, en waarin hulle as denkbeeldige broers en susters van mekaar in gehoorsaamheid aan die wil van die Vader vir mekaar sorg dra.

Sy leringe was mondeling van aard en het bestaan uit kort gelykenisse en dikwels uit skerp 'een-lyn' spreuke. 'n Voorbeeld van 'n kort gelykenis is dat die koninkryk van God vergelyk word met die geringe, onrein mosterdsaad wat die groot, apokaliptiese boom verdring, verwysende na die wêreldryke van Nebukadnesar (Dan 4:10-12), die Farao en die koning van Assirië (Eseg 31) en die keiser van Rome (Lukasevangelie). Een-lyn spreuke is: 'Laat die dooies hulle eie dooies begrawe!' en 'Niemand kan twee here dien nie'! Die strekking in beide hierdie twee tipe vorms was 'skokkend' en het die hoorders uitgelok tot nuwe persepsies oor ou konvensionele kultuuropvattings. Laasgenoemde is voorgestel as onder andere die 'breë weg' teenoor die nuwe as die 'nou weg'.

Sy 'alternatiewe wysheid' het 'n gans andere voorstelling gebied as die konvensionele oor die rol van die kultus, oor wat rein en onrein is, oor Leviet, priester en Samaritaan, oor by wie God teenwoordig is, oor vrouens en kinders, heidene en uitgestotenes. Dit was in tweërlei opsigte nie heeltemal uniek nie: dit het aangesluit by enersyds die kritiek in die boeke Job en Prediker teen die 'vergeldingsdogma' van 'n oog om 'n oog, en andersyds by die profetiese kritiek teen die onreg wat hooggeplaastes teen geringes pleeg. Aan die anderkant was dit weer in tweërlei opsigte wel uniek deurdat dit enersyds die indirekte bemiddeling deur middel van die 'versoeningshandelinge' in die kultus deur die priesters en die offerritueel waardeur die mens in die regte verhouding met God gestel kon word, ontken het en andersyds die nasionale en patriargale voorkeure bevraagteken het. Vanweë sy konsistente en onverskrokke onkonvensionele houding en optrede met betrekking tot veral die tempelideologie het Jesus met die Fariseërs in konflik gekom en is Hy deur Saddusese priesterhooofde en familiehoofde as 'n bedreiging ervaar. Sy dood is treffend deur Lukas in die gelykenis van die ryk man en Lasarus uitgebeeld: Làsarus, die enigste karakter wat in die gelykenisse 'n naam het en dit beteken 'God help', is die arme man wat net dit wat sleg is, ontvang! Lukas - deur sy lesers/hoorders te herinner aan Jesus se besondere interpretasie van 'Moses en die Profete' en dieselfde later in die Emmausverhaal te doen gee aan die ryk man se vraag in die gelykenis van die ryk man en Lasarus ' $n$ betekenis wat nie onbelangrik is nie: 'sal ons eers glo as iemand uit die dood opstaan?' 
Die naam 'Jesus' was een van die mees algemene name onder die Israeliete. So ook die naam van sy ma en die naam 'Josef', die man wat volgens die tradisie Maria en haar kind in sy huis opgeneem het. Jesus het broers en susters gehad, maar hulle word alleen in laat Nuwe-Testamentiese apokriewe (Proto-Jakobus en Pseudo-Matteus) direk 'kinders van Josef' genoem. Een van sy broers, Jakobus, het na Jesus se dood 'n belangrike man in Jerusalem en in die Jerusalemse kerk geword. Volgens getuienis het hy 'n 'visioenêre ervaring' van sy gekruisigde broer gehad. Dit is duidelik dat Jesus na sy dood deur besondere 'vriende', soos Petrus en Maria Magdalena, en ook deur 'nuwe vriende', soos Jakobus, maar ook Paulus, die Gesalfde van God, Israel se Messias, genoem is. Hierdie benaming dui daarop dat die gekruisigde Jesus die eretitel Seun van Dawid waardig geag is (kyk Rom 1:3). God het 'Christus Jesus' in heerlikheid verhoog, het onbekendes voór Paulus bely en Paulus het hierdie belydenis sy eie gemaak en dit in sy brief aan die Filippense (2:5-11) op skrif gestel. Daarom het ook Paulus vir Jesus Christus met die naam Kurios vereer - ons vertaal dit met 'Here'. Dit is 'n erenaam wat vir onder andere wêreldheersers met invloed ver buite hulle geboortegrond gegee is, soos die keisers van Rome. In die Griekse vertaling van die Ou Testament is God ook onder andere só genoem.

Mense met sulke majesteit was in die oë van hulle vereerders 'godeseuns', mense met goddelike herkoms, mense wie se lewe nie deur dood beëindig word nie - nie 'n vreemde gedagte in 'n wêreld waar die dooies in logiese verlengstuk met die lewendes gesien word nie! Ook vir Paulus is die herkoms en bestemming van 'Jesus Christus ons Here' terug te voer na grense ver buite die Israel van ouds; ja, selfs anderkant alles wat sigbaar en onsigbaar is, alles wat God geskep het - dit wil sê pre-eksistent en posteksistent. Skrywers wat die Pauliniese tradisie verder gedra het, soos die outeur van die brief aan die Kolossense (1:15-20), het hierdie ortuiging treffend in belydenisvorm geformuleer.

Histories gesien, was sommige van die 'godeseuns' waarvan ons in die GrieksRomeinse literatuur lees, moontlik nie werklike mense van 'vlees en bloed' nie, byvoorbeeld die 'godmens' met die beroemde genesingskrag, Asklepius, seun van Apollo. Ander was ongetwyfeld historiese persone. Ons dink an onder andere Aleksander die Grote, Augustus en Domitianus. Ook oor die DAT van die historiese bestaan van Jesus van Nasaret behoort niemand twyfel te he nie.

Wie is nou die 'werklike Jesus'? Is die Jesus wat ons as Christene sedert voor die vyftigerjare van ons jaartelling vir bykans tweeduisendjaar bely en verkondig as die Messias van Israel, Here van die wêreld, die Seun van God, God self, gelyk in wese met die Vader (sedert die vierde eeu) en met die Gees (sedert die agtste eeu, en vanaf die begin van die elfde eeu op 'n sekere manier in die Westerse kerk geformuleer) die 'werklike Jesus'? Diegene wat op grond van die vroëre kenteoretiese visies in die naturwetenskap slegs die fisiese waarneembare as werklik ag, sal waarskynlik alleen Jesus se 'menswees', die feit dat Hy die 'seun van Maria' is, as die 'werklike Jesus' 
beskou en nie die geloofsoortuiging dat Jesus, die 'Seun van God' is nie! Ek kan my die redes voorstel waarom godsdiensveragters sedert die Verligting vir die laaste opsie kies. Dit kom daarop neer dat die historiese Jesus die 'werklike Jesus' is en nie die Jesus van die geloof nie. Ek kan my egter nie voorstel dat Christene só eensydig onreligieus kan wees nie!

Wie behoort dan volgens Christene die 'werklike Jesus' te wees? Sommige sê dat dit dié Jesus is waarvan in die Bybel alleen gepraat word, en ander sal byvoég: dié Jesus waarvan ó́k die kerklike belydenisskrifte getuig. Dit sal daarop neerkom dat die 'werklike Jesus' dié Jesus is wat in die kanon verkondig en in die kerk se ander normatiewe geskrifte bely word. Maar glo ons in woorde, in dooie letters op ink? Of glo ons in die Woord waarvan die woorde (in die kanon en in die belydenisskrifte) getuig, dit wil sê die Kanon vớr die kanon.

Persoonlik het ek tot die oortuiging gekom dat my geloof nie moet opgaan in dit wat ander mense sê hulle glo nie. Dit sou op 'fideisme' neerkom. Ander se geloof kan wel vir jou belangrike riglyne en spreekreëls bevat en dit kan selfs per ooreenkoms as die norm vir kerklike verkondiging dien. Maar in wese is geloof iets persoonliks. Geloof is nie die intellektuele beheersing en aanvaarding van ander mense se stellings oor God of oor hulle geloof in God nie. Geloof is 'n verhouding, 'n ontmoeting, met God wat kennis van sy Woord veronderstel asook 'n vertroue in God self. Die dimensies 'kennis' en 'vertroue' is in hierdie gebeure onlosmaaklik ineengevleg.

Vir my is Jesus van Nasaret die manifestasie van God. Die 'werklike Jesus' is vir my die Jesus wat die 'Seun van God' is én die Jesus wat die 'seun van Maria' was, die Jesus van die geloof én die Jesus van die geskiedenis in onlosmaaklike twee-eertheid. Dit is hierdie Jesus wat die voorwerp van die kerklike verkondiging en belydenis behoort te wees.

Geloof is vir my gegrond in God wat die nederige verhoog. Jesus van Nasaret is die nederige wat deur God verhoog is - nie in die sin van twee opeenvolgende stadia, eers die nederige, historiese Jesus en dan die verhoogde, kerugmatiese Christus nie. Die God wat ek ontmoet, is die God wat my midde-in my nietigheid, my doodsbestaan, die lewe skenk. My geloof dat ek, 'ellendige mens', 'in Christus', 'in die Here', 'in die Gees' is - om Paulus se formules te gebruik - is gegrond in Jesus WAT op so 'n wyse gebore is, WAT op so 'n wyse gepraat en opgetree het en WAT op so 'n wyse gesterf het, DAT die evangelie paradoksaal die blye tyding vanwee God se Gees is, te wete DAT lewe midde-in dood, vreugde midde-in aanvegting, moontlik is.

Indien die 'werklike Jesus' slegs die 'opgestane Jesus' sou wees en nie ook meteen die 'gekruisigde Jesus'. nie, die na-Pase en die historiese Jesus ineen, sou die evangelie dooie letters op ink wees en nie woorde van die Gees wat midde-in 'n verwronge wêreld sin gee nie. Wat is my gevolgtrekking? Die 'werklike Jesus' is die Jesus van die geskiedenis wat deur die kerk as Christus en Here geglo, bely en verkondig word. 


\section{WAAROM DIE HISTORIESE JESUS-VRAAG?}

Die belang van die ondersoek na die historiese Jesus kan vanuit verskeie hoeke benader word. Die kerk is byvoorbeeld een van die invalshoeke, en die universiteit ' $n$ ander.

\subsection{Vanuit die gesigspunt van die kerk}

Die verkondiging en die belydenis van die kerk het nie die aanspraak van vry wees van toetsing nie. Die maatstawwe van toetsing kan verskillende vorme aanneem na gelang van die geldende wetenskapsbeeld. Hier moet onthou word dat die spreekreëls van die kerk onder alle omstandighede gebind behoort te wees aan die evangelie van Jesus Christus. Die kerk is die draer van die evangelie. Daarom kan dit wees dat mense vandag die geldigheid van die kerk se spreke sal wil toets aan die hand van die aard var. die konkrete uitwerking van die evangelie van Jesus Christus in kerk en in wêreld. Hier geld met ander woorde 'falsifikasie' as die wetenskapskriterium. Sommige kan selfs meen dat die sukses van die kerk se spreke gesien kan word in die mate van die kerk se lojaliteit aan die spreke wat in die kanon en in die ander normatiewe geskrifte van die kerk gevind word.

Hoe ook al sy, die kerk het inherent die moontlikheid om, meestal onwetend, die evangelie van Jesus Christus te vervals en te verduister, te manipuleer of selfs (A)nder in die naam van die evangelie te manipuleer en só van die evangelie en van dié Een waarvan dit getuig, te vervreem. Hierdie moontlikheid was reeds by die vroegste kerk aanwesig, ook by diegene wat die Jesus-tradisies mondeling oorgelewer het, diegene wat dit neergeskryf en redaksioneel verwerk het, asook diegene wat die sewe en twintig geskrifte as die Nuwe Testament gekanoniseer het.

Gewoonlik bely ons dat hierdie proses van tradisie-oorlewering en opskrifstelling van die Bybel onder leiding van die werk van die Heilige Gees geskied het. Die werk van die Heilige Gees word egter nie deur my as meganies voorgestel of beleef nie. Die Heilige Gees ontneem nie die menslikheid van die Bybelskrywers en van diegene wat vóór hulle die evangelie oorgelewer het en ook nie van diegene wat ná hulle dit geïnterpreteer het nie. Dit wat eenmaal in die kanon opgeneem is, het tog nie die aardse of menslike karakter verloor nie. 'n Ampsbeskouing met 'n verwronge magsaanspraak en 'n onwaardige teneerdrukking van vrou en kind is maar twee verskynsels in die samelewing wat tot in die patriargale leefwèreld van die kanon teruggevind kan word, deur die kanon selfs betuig word, maar nie na Jesus van Nasaret teruggevoer kan word nie.

Die Nuwe-Testamentiese wetenskap is per definisie ondersoekend gemoeid met die vraag na die verhouding tussen wat daar oor Jesus bely is en wat Jesus self sou gesê en gedoen het. Ten spyte van die eie vooronderstellings wat 'n rol gespeel het in die wetenskaplike se historiese Jesus-konstruk, ten spyte van selfs die leemtes wat in 'n bepaalde konstruk kan bestaan en ten spyte van die verskeidenheid van Jesus-konstrukte, bly die ondersoek na Jesus die kerk herinner aan die Jesus AGTER die belyde- 
nis van die geloof en die verkondiging van die Woord. Is dit nie maar wat Martin Luther ons met sy Strewe-na-Christus-beginsel geleer het nie! Dit is ook wat ek met die uitdrukking die 'Kanon VOOR die kanon' bedoel.

Ek ag, met ander woorde, dié Kanon as die toetssteen van geloof en lewe. Só sien ek myself in die geselskap van Luther. Hy het na Christus as die Prüfstein verwys en hierdie verwysing gekwalifiseer as das in der Bibel sprechende Wort als den Mutterschoß der Kirche. Hierdie strewe is nie 'n pleidooi vir subjektiewe relatiwisme nie. Ons weet dat Luther sy Strewe-na-Christus-beginsel inhoudelik ingevul het met Paulus se gedagte van regverdiging deur die geloof alleen. Hoewel hierdie uitdrukking nie in al die geskrifte van die Bybel voorkom nie, nie eens in al Paulus se geskrifte nie, ag ek dit saam met Luther as die Kanon des Kanons. Ek sien dit as die kern van die saak waarvoor die historiese Jesus gestaan het.

Hierdie saak is weliswaar op diverse wyses deur die vroegste kerk, vanweë die Paas-tradisie gedring tot helydenis van geloof en verkondiging van die evangelie, gekontinueer. Afgesien van die wetenskaplike meriete van die historiese Jesusondersoek, omdat dit ons help om die oorleweringsproses agter die ontstaan van die Nuwe Testament verantwoordelik te verduidelik, kan die kerk met behulp van hierdie ondersoek tot groter helderheid met betrekking tot die selfverstaan van die Christendom kom. Hierdie wins van die historiese Jesus-ondersoek het Ernst Käsemann 'n 'wenslikheid na-binne gerig' genoem. Maar daar is ook 'n wenslikheid wat na-buite gerig is, het Käsemann gesê. Die kerk het die ondersoek na die historiese Jesus ook nodig ter wille van die apostolaat van die kerk.

Op die weg van die sendende kerk in die wêreld word die kerk gekonfrontear met die vraag: wie is die Jesus wat jy bely en verkondig en waartoe jy ons uitnooi om Hom as ons saligmaker aan te neem? Hoe is dit dat Hy wat 'n partikuliere Jood van Galilea was, voorgehou word as die universele verlosser? 'n Karakter van papier sonder 'vlees en bloed' sal in 'n sendingsituasie 'n gebrek aan geloofwaardigheid hê! Indien ons nie die vraag na die historiese Jesus vra nie, kan die kerugma en die kerklike belydenis 'n ideologie word wat gemanipuleer word net soos mense wil, het Käsemann gesê. As ons ons herinner aan die beelde van Christus wat tydens kruisvaarttogte, in kolonisasie in die naam van sending en in gaskamers aan mense van ander godsdienstige oortuigings voorgehou is, help die historiese Jesus-vraag ons om onder andere die inklusiewe betekenis en die anti-hiërargiese betekenis van die evangelie te herontdek.

\subsection{Vanuit die gesigspunt van die universiteit}

Jesus van Nasaret is lank nie meer die alleenbesit van die kerk nie! Hiermee is die alleengeldigheid van die 'kerugmatiese Christus' in gedrang asook die voorrang van die 'verkondigde Christus' bó die 'verkondigende Jesus'. Of ons daarvan hou of nie, die 
belang van die Jesus-vraag strek verder as die eredienste op Sondae in kèrkgeboue, verder as die normatiewe geskrifte van die amptelike kerk, verder as die apostolaat van die sendende kerk, verder as die god-talk van Christene op straat. Dink maar net aan novelles soos dié van die Egiptiese medikus, M Kamel Hussein, getitel City of Wrong: A Friday in Jerusalem (geskryf in Arabies 1959; vertaal in Engels 1966) en dié van die Heidelbergse teoloog, Gerd Theissen, getitel The Shadow of the Galilean (geskryf in Duits; vertaal in Engels 1987). Jesus verskyn nie in een van hierdie twee boeke as karakter nie, maar die plot van beide sentreer in die singewing wat konfrontasie met Jesus van Nasaret skep. Hussein vertel van die profetelot van 'n 'Moslem Jesus' in die moorddadige stad Jerusalem. Theissen vertel van 'n 'polities misverstane Jesus'. Beide romanskrywers baseer hulle onderskeie twintigste-eeuse anakronistiese beelde van Jesus op historiese navorsing. So is daar ook werke van mense oor Jesus soos dié van Bruce Barton, die Amerikaanse advertensiemagnaat, wat met sy boek The Man Nobody Knows (1925) kapitalisme verdedig as in ooreenstemming met die boodskap van Jesus. Die skrywer wil met die titel van sy boek sê dat niemand anders as hyself nou eers vir die eerste keer hierdie insig bekendmaak nie. Maar voldoen dit aan historiese Jesus-navorsing? Die sosialis, Upton Sinclair, uitgaande van opmerkings van die Joodse gekiedskrywer, Josefus, wou weer met sy boek, Personal Jesus: Portrait and Interpretation (1952), kapitalisme kritiseer. Die Praagse filosoof, Milan Machoveč, grond ook sy boek, A Marxist looks at Jesus (geskryf in Duits 1972; vertaal in Engels 1977), op historiese Jesus-navorsing en maak daarmee 'n singewende dialoog tussen Christene en Marxiste moontlik. Veel meer boeke kan hier opgenoem word, ook dié wat in Suid-Afrika geskryf is. Hierby kan die talle kunswerke van skilders, musici, digters, dramaturge, draaiboekskrywers van verhoogstukke en films genoem word.

Die eerste Jesus-film, From the Manger to the Cross, is reeds in 1913 vervaardig en dit getuig van naiëwe harmoniserings van temas in die Bybel. In die sestigerjare kom die eerste pogings in die filmbedryf vorendag om die evangelies 'n bietjie te interpreteer, soos gesien kan word in byvoorbeeld King of Kings. Die sewentigerjare word gekenmerk deur eksperimentering van ander verfilmingsmoontlikhede, byvoorbeeld die algemeen aanvaarde Jesus Christ Superstar en Godspell. Hierdie gewilde kontemporêre musiekblyspele met New York as agtergrond getuig weer van 'n vrye omgang met die Bybel. Die tagtigerjare se twee Jesus-films is modern-filosofiese interpretasies en wek onderskeidelik aanvaarding en verwerping, te wete Jesus of Montreal (1989) en die omstrede The Last Temptation of Christ (1988). Eersgenoemde handel oor 'n passiespel in Montreal en die kerk se aandrang op Skrifgetrouheid, terwyl laasgenoemde 'n 'alternatiewe Jesus' uitbeeld teen die agtergrond van die na-oorlogse gees van suspisie 
en die vraag na die menslikheid van Jesus: aan die kruis ervaar Jesus 'n illusie, kom van die kruis af, leef as 'gewone mens', trou en verwek kinders, en worstel met die vraag of dié konvensies singewend is. Deesdae, reeds die tyd vooruit, word wyd berig gegee van die ver gevorderde draaiboek van Paul Verhoeven. Hierdie filmmaker van Los Angeles het 'n doktorsgraad in die teologie, verkry in Leiden, Nederland. Hy het deurgaans vir tien jaar by dr Robert Funk se Jesus Seminar ingesit en dié gebruik as konsultasiespan met die oog op advies vir die daarstel van die grondplan van sy beplande Jesus-film.

Van die Jesus Seminar gepraat, die berig (nie so noukeurig soos 'n mens sou wou hê nie) wat in Time se uitgawe van 8 April 1996 oor vanjaar en verlede jaar se werksaamhede van die Jesus Seminar verskyn het, het in die eerste enkele dae nadat die uitgawe verskyn het, 600 briewe van orals in die wêreld, ook vanuit Suid-Afrika, na die redaksiekantoor laat stroom (kyk die briefkolom van die uitgawe van 29 April 1996). In die uitgawe van 15 Augustus 1988 het 'n artikel in Time verskyn met die opskrif 'Who Was Jesus?'. Dit het 2100 briefreaksies veroorsaak! Geen wonder dat die redakteur in die uitgawe van 29 April 1996 (bl 6) onder die opskrif, 'Jesus Christ, Superstar', skryf: 'Hoewel lesers vrae kan hê oor verskillende teorieë ten opsigte van wat geskiedenis is en skepties kan wees oor sekere gesigspunte [van Bybelwetenskaplikes], is éen ding ongetwyfeld seker: godsdiens is gewis 'n sentrale besprekingspunt'.

Kan 'n mens jou die gebrek aan diens aan 'n plurale gemeenskap voorstel, indien navorsers, soos dié verbonde aạn die Jesus Seminar, of dié verbonde aan universiteite, ook in Suid-Afrika, nie kans sou sien om basiese en fundamentele navorsing oor die historiese oorspronge van die Christendom of oor die Jesus van die geskiedenis te onderneem nie! Net soos diegene in die kerk deur historiese Jesus-navorsing herinner kan word aan die moontlikheid van vervreemding aan die Jesus van die geskiedenis, so ook diegene in die nie-Christelike, post-Christelike of plurale godsdiensgemeenskap.

\section{HISTORISITEIT - LANGS WATTER WEG?}

Die toegang wat navorsers tot die Jesus van die geskiedenis het, geskied nie anders as deur die pad te baan deur die literêre getuienis, in die Skriftuurlike en dogmatiese tradisies, oor die Jesus van die geloof nie. Hier geld egter nie die voorkeure wat die geskrifte in die kanon met betrekking tot die kerklike verkondiging of geloofsbelydenis het nie. Die historiese wetenskap kan nie deur die geloof van mense geprejudiseer word nie. Alle tersake tekste of artifakte word aan dieselfde historiese oordeel onderwerp.

Jesus het nie self die boodskap van sy woorde en dade, of die betekenis van sy geboorte en dood, neergeskryf nie. Dit sou buitendien baie vreemd gewees het, indien 'n skrynwerker wat jukke en deurkosyne gemaak het, iemand waarskynlik soos Jesus 
wat part en deel van die kleinboerderygemeenskap van eerste-eeuse Galilea was, ooit self sou kon geskryf of gelees het! Ek sê dit ten spyte van die tendensieuse berig in Lukas 4:16 dat Jesus in 'n sinagoge uit Jesaja 61 voorgelees het en op Homself van toepassing gemaak het. Hierdie gedeelte is sprekend van die evangelis se na-Pase geloofsoortuiging dat Jesus die Messias van Israel is.

Die verskillende kante van die invloedrykheid van Jesus se lewe is eers ná sy dood oorgelewer deur diegene wat God, op grond van die lewe van Jesus, ontmoet het. Dit het eers mondeling gebeur en die eèrste skriftelike neerslag wat ons vandag in die Nuwe Testament aantref, het ongeveer vyf en twintig jaar ná sy dood plaasgevind - en dit deur iemand wat Hom nooit self persoonlik geken het nie: Paulus van Tarsus! Die Markusevangelie, geskryf ongveer $70 \mathrm{n} \mathrm{C}$, het daarna gevolg. Markus het as bron vir die skrywers van die Lukasevangelie (geskryf ongeveer $85 \mathrm{n} \mathrm{C}$ ) en die Matteusevangelie (geskryf ongeveer 85-95 n C) gedien. Die Johannesevangelie het teen die einde van die eerste eeu onafhanklik van die ander drie kanonieke evangelies ontstaan.

Hierby moet ons nie die wyse vergeet waarop die dokumente van die Nuwe Testament geproduseer en gereproduseer is nie. Vóór die ontdekking van die boekdrukkuns deur Johann Gutenberg rondom $1450 \mathrm{n} \mathrm{C}$ is boeke met die hand geskryf, oorgeskryf en vertaal. Hierdie manuskripte het eers in boekvorm in $300 \mathrm{n} \mathrm{C}$ verskyn. Die oorspronklike manuskripte van die Nuwe Testament (die eerste grondteks) bestaan nie meer nie. Die vroegste klein fragmente van manuskripte wat bestaan, dateer uit die tyd vanaf $125 \mathrm{n}$ C. Die vroegste groot fragmente van manuskripte wat bestaan, kom uit die tyd vanaf $200 \mathrm{n} \mathrm{C}$ en die vroegste volledige bestaande manuskrip van 'n boek in die Nuwe Testament uit die tyd vanaf 300 n C. Geen een van die manuskripte van dieselfde boek in die Nuwe Testament van vó́r 1454 kom volledig met mekaar ooreen nie. In die proses van die oorskryf en vertaal van manuskripte het talle 'foute' ingesluip. Die vasstelling van 'n betroubare Nuwe Testament vereis 'n histories-vergelykende ondersoek. Nie net daardie manuskripte wat in die Nuwe Testament neerslag gevind het, kan as deel van die agenda van hięrdie teks-historiese navorsing gemaak word nie. Geen getuienis wat ter sake is, mag geignoreer word nie! 'n Span van historici wat hulle besig hou met die oorspronge van die Nuwe Testament, het onder beskerming van die United Bible Societies in komitee en by wyse van stemming keuses uitgeoefen en die resultate in vier grade van meer waarskynlikheid na minder waarskynlikheid gerangskik en gepubliseer. Die eindproduk is die Nuwe Testament wat in kerke, in huise en in hotelle deur Christene en nie-Christene gelees, gewaardeer of verwerp word.

Dieselfde histories-vergelykende werkwyse en dieselfde wyse van komiteewerk en stemming as wat by die samestelling van die Nuwe Testament gegeld het, is deur die Jesus Seminar in die ondersoek na die historiese Jesus gevolg. Hierdie tipe historiese beslissings word veral gelei deur die kriterium wat bekendstaan as 'meerdere onaf- 
hanklike literêre getuienis'. Hiermee word bedoel dat meerdere onafhanklike skriftelike getuienis groter historiese waarskynlikheid as enkelvoudige getuienis het of as meervoudige literêre getuienis wat van mekaar afhanklik is. Verder word in ag geneem dat materiaal dikwels deur skrywers gewysig is om eie intensies en narratiewe strukture te pas. Sulke stof en uitsprake wat duidelik die literêre voorkeur van 'n bepaalde skrywer en die kenmerke van 'n na-Pase gemeentelike lewenssituasie (Sitz im Leben) vertoon, is dikwels direktiewe van daardie Jesus-tradisies wat histories nie na die mondelinge periode van 30-50 n C teruggevoer kan word nie. Sulke redaksionele materiaal kan nouliks as elemente van die historiese Jesus geag word. Daar word in hierdie soort historiese navorsing van die aanname uitgegaan dat, net soos skrywers algemene 'wysheid' uit hulle leefwêreld in die mond gelê het van, of van toepassing gemaak het op, legendariese wysgere soos Salomo en Sokrates, die volgelinge van Jesus dieselfde gedoen het. So byvoorbeeld het Matteus besondere moeite gedoen om Jesus konform die Griekse vertaling van die Ou Testament (die Septuagint) voor te stel en het hy in hierdie proses veral gebruik gemaak van apokalipties-messiaanse temas wat kom uit die gemeenskaplike leefwêreld van die laat eerste-eeuse Joods-Griekse wêreld. Ons dink in die besonder aan sekere Ou-Testamentiese pseudepigrawe. Lukas weer, hoewel heelwat van die tradisies in sy bronne op Palestynse bodem ontstaan het, kompeteer in sy voorstelling van Jesus met 'propaganda-motiewe' wat voorkom in Grieks-Romeinse godeverhale en in die keiserkultus. Laasgenoemde aanname hou verband met wat as die 'verchristeliking' (in Duits: Christianisierung) van Jesus genoem kan word. Spore hiervan is reeds in die Nuwe Testament aanwesig, maar trajekte kan tot diep in die tweede eeu en selfs daarna aangetoon word. So byvoorbeeld vertoon sekere uitsprake van Jesus duidelik die kenmerke van Christene se na-Pase geloofsoortuigings. Hiermee hang saam die verskynsel dat die Christelike geloofsgemeenskap sekere apologetiese stellings ontwerp het om smeerveldtogte van opponente teen te staan en is hierdie stellings in die mond van Jesus gelè. Noukeurige oorweging van al hierdie gegewens help ons om ' $n$ bepaalde beeld van die historiese Jesus daar te stel wat duidelik te onderskei is van die Jesus-beelde van die skrywers van kanonieke en nie-kanonieke evangelies. Van die nie-kanonieke evangelies wat in hierdie ondersoek belangrik is, kan veral die Thomasevangelie en die Evangelie van Petrus genoem word. Eersgenoemde evangelie is deel van die biblioteek wat in Nag Hammadi, Bo-Egipte, in 1945 ontdek is.

In hierdie ondersoek word historiese beslissings nie afhanklik gemaak van dit wat moderne mense in die Westerse tradisie rasioneel in hulle leefwerreld as moontlik of aanvaarbaar ag nie. In die eerste-eeuse kulturele wêreld van die mense in die gebied rondom die Middellandse See het geesteservarings 'n psigo-religieuse toestand by 
sekere charismatiese mense veroorsaak wat genoem kan word "'n alternatiewe staat van bewussyn'. Sonder hierdie insig vanuit die kultuurpsigologie sal positiwiste met 'n empiriese wetenskapbenadering nie die alternatiewe werklikheid van geloofsgenesings en opstandingservarings in die leefwêreld van Jesus insien nie. Daarom is dit belangrik om daarop te let dat die historiese Jesus-vraag deesdae sterk gekenmerk word deur die multidissiplinêre aard daarvan. Bybelse Argeologie, Sosiologie, Kulturele Antropologie, Psigobiografie, Mediese Antropologie en Sosiolinguïstiek is van die dissiplines wat die histories-kritiese eksegetiese ondersoek na die historiese Jesus onderbou.

Persoonlik gaan my eie historiese Jesus-navorsing uit van 'n historiese model wat ontleen is aan die Duitse sosioloog, Max Weber, se konsep 'ideaal-tipe'. Met hierdie model poog ek nie om 'n geskiedskrywing van konkrete historiese situasies op grond van empiriese data daar te stel nie. ' $n$ 'Ideaal-tipe' is 'n teoretiese konstruksie waarin moontlike gebeure verstaanbaar in verband met mekaar gestel word, sodat 'n koherente beeld van gegewens uit die verlede gevorm kan word. Met ander woorde, as teoretiese konstruk is ' $n$ 'ideaal-tipe' 'n gedagtekonstruk wat nie noodwendig empiries in die werklikheid teruggevind hoef te word nie. As 'n konstruk wat 'n koherente beeld vertoon, beïnvloed die 'ideaal-tipe' wel die voorwaardes van ondersoeke na dit wat histories werklik kon gebeur het, deurdat dit die bedoeling van die daarstel van 'n 'ideaaltipe' is om die onderlinge verhoudinge tussen die afsonderlike historiese gebeurtenisse verstaanbaar uiteen te sit. So 'n koherente konstruk word nie gevorm deur en is nie gebaseer op 'n keuse vanuit dit wat as universeel geldig geag word nie, dit wil sê dit wat gemeenskaplik is aan alle tersake gevalle van soortgelyke konkrete situasies van wat werklik kon gebeur het nie. Dit is dus nie 'n logies-positiewe keuse wat berus op of induktiewe of deduktiewe argumentvoering nie.

In alle beskeidenheid, my bydrae tot historiese Jesus-navorsing is die daarstelling van 'n konstruk van Jesus as 'n 'vaderlose' figuur wat God sy Vader (in Aramees: $A b b a$ ) genoem het. Deur in my historiese ondersoek bewustelik van die sosiaalwetenskaplike model van 'n 'ideaal-tipe' uit te gaan, maak ek dus nie aanspraak daarop dat my historiese Jesus-konstruk sou berus op wat gemeenskaplik aan alle 'vaderlose' persone in die eerste-eeuse Galilese situasie sou wees nie. Dit sou op 'n induktiewe historiese argumentvoering neerkom. My Jesus-konstruk berus ook nie op dit wat gemeenskaplik is aan die meeste tipe gevalle van 'vaderlose' persone in die Galilese situasie nie. Dit sou weer op 'n deduktiewe historiese argumentvoering neerkom. Met die model van 'ideaal-tipe' word gekonsentreer op die mees 'gunstige' gevalle. Wat hiermee bedoel wòrd, is dat ek in my ondersoek na die Jesus van die geskiedenis fokus op daardie data wat kan lei tot 'n beter verstaan en verduideliking van die geheelprentjie en besondere aspekte in die geheelprentjie. Ek is veral geinteresseerd in die vraag 
waarom die historiese Jesus by Johannes die Doper aansluiting gevind het en die 'doop tot vergifnis van sonde' ondergaan het en waarom Jesus, nadat sy pad van die Doperkring geskei het, só onkonvensioneel vir sy tyd gemoeid geraak het met die lot van sosiaal uitgestotenes, veral vrouens en kinders. Ek vind 'n verduideliking op hierdie vrae deur middel van my konstruk van Jesus as die 'vaderlose seun van God'. Hierdie sake sal in my beplande boek oor Jesus detail aandag ontvang. Hier wil ek alleen beklemtoon dat dit die taak van historiese navorsing is om in elke besondere geval of konkrete historiese situasie, sover as wat dit moontlik is, te bepaal in watter mate die betrokke teoretiese konstruk naastenby ooreenkom of afwyk van wat werklik kon gebeur het. Vir sover as wat die historiese situasie voldoen aan die voorwaardes van die konstruk, is die historiese situasie verhelder. Vir sover as wat die historiese situasie nie voldoen aan die voorwaardes van die konstruk nie, is aspekte in die historiese navorsing uitgelig wat andersins onopgemerk sou gebly het.

\section{SY GEBOORTE EN OPSTANDING}

Die boek wat ek besig is om oor Jesus te skryf, sal hoofsaaklik handel oor 'n verduideliking van Jesus se gelykenisse en genesings teen die agtergrond van sy geboorte. Vanweë gebrek aan ruimte en tyd konsentreer ek in hierdie voordrag hoofsaaklik op die tema 'vaderloosheid'. Maar ook hierdie tema word hier slegs kursories aangeraak. In my boek oor Iesus sal ek hieroor en oor die ander aspekte in die geheelprentjie hierbo meer breedvcerig wees. Maar ter wille van moontlike nuuskierigheid, gaan ek eers baie kortliks in op die opstanding van Jesus.

\subsection{Sy opstanding}

My verstaan van die meeste van die opstandingsberigte hou verband met die insig dat dit geloofsoortuigings is wat spreek van wat ek vroeër in hierdie voordrag die 'alternatiewe staat van bewussyn' genoem het. Ek ontken dus nie die werklikheid van die verskynings van die gekruisigde Jesus nie, net soos ek nie die werklikheid van Jesus se 'coping-healings' ontken nie. 'n Vergelykende historiese ondersoek na die literêre getuienis in hierdie verband bevestig veral die verskynings aan Paulus, Petrus en moontlik ook Maria Magadalena. Die berigte oor hierdie verskynings hou veral verband met die interpretasie van Jesus se dood en die vraag hoe die aanstoot van die kruisiging oorkom kan word. By Petrus het ons moontlik te doen met ' $n$ intènse berou or verloëning, by Paulus met 'n berou oor vervolging en die insig in ' $n$ herdefinisie van die uitdrukking 'kinders van Abraham', by Maria Magdalena met 'n intense persoonlike verlange en herinnering. Dit lyk asof die aanstoot deur hulle oorkom is, deurdat hulleself paradoksaal triomferende kruisdraers geword het. 
Ek het nie twyfel daaroor dat die corspronge van die Nuwe-Testamentiese Christendom geleë is in die geloofsoortuiging met betrekking tot die opstanding van Jesus Christus en die Geesvervulde lewe van gelowiges in die eenheid met die opgestane Here nie. Ek is bewus van strominge in die vroegste Christendom wat wel sinvol gelowiges sonder Pase was (bv die onderskeie gemeenskappe in terme waarvan die Spreuke-Evangelie $Q$ en die Thomasevangelie geskryf is). Die Christendom waarvan die Nuwe Testament getuig, is egter nie sonder Pase denkbaar nie. Jesus se interpretasie van die koninkryk van God, sy wysheid, sy herdefiniëring van die konsep 'kinders van Abraham', dit wil sê 'kinders van God', konstitueer die wesenlike van Christelike selfverstaan. Die wesenlike van die godsdiens is om te doen wat by God pas (Rom 12:1-2). Indien verwerping en dood as 'n mislukking, dwaasheid of aanstoot gesien sou word, het Jesus se visie 'gefaal'. Maar hierdie paradoksale en aanstootlike persepsie dat krag in swakheid, wysheid in dwaasheid, eer in skande, lewe in sterwe moontlik is, behoort volgens die evangelie van Jesus Christus deel te wees van Christelike selfverstaan. Omdat God skande in eer omkeer, is die geloofsoortuiging met betrekking tot die opstanding die teken van 'n nuwe geboorte, 'n nuwe begin, ' $n$ nuwe skepping (2 Kor 5:17; Gal 6:15): die geboorte van die 'ware Israel', die 'Israel van God' (Gal 6:16).

Indien die verskillende berigte oor die opstanding in die Nuwe Testament deur die lens van 'n logies-positiwistiese ondersoek na kontroleerbare eksakthede geīnterpreteer sou word, sal daar gou gestuit word voor vrae soos: wie het nou werklik op die opstandingsdag na Jesus se graf gegaan, wanneer presies is daar gegaan en waarom is daar gegaan? Die probleem is egter dat die diverse gegewens in die Nuwe Testament nie 'n eksakte historiese beslissing toelaat nie! Dieselfde geld met 'n vraag soos: hoeveel engele is in of rondom die graf gesien? Wat het die engel of engele aan die vroue gesê? Wat het die vroue gedoen na hulle ontmoeting met die engele? Wie het eerste die opgestane Jesus gesien? Hoe dikwels het die opgestane Jesus aan die dissipels verskyn, aan watter dissipels, waar en wanneer? Gaan die opstanding van Jesus gepaard met sy gawe van die Heilige Gees aan die dissipels, en indien wel, wanneer het dit gebeur? Wanneer het die opgestane Jesus sigbaar en liggaamlik ten aanskoue van die dissipels opgevaar (net Lukas berig só): op Paas-Sondag of veertig dae later op Hemelvaart-Donderdag? (Lukas berig beide datums.)

Histories gesien, gaan ons baie verder kom deur die klem te lê op 'n beskrywing van die ontwikkelingstrajek wat daar met betrekking tot die berigte oor die opstanding van Jesus Christus teenwoordig is. Die eerste uitsprake wat ons in die dokumente van Christene in hierdie verband na die dood van Jesus in ongeveer $27 \mathrm{n} \mathrm{C}$ aantref, is dié wat uit die periode 27-50 n C kom. Dit bely enkelvoudig dat Jesus 'verhoog' is (die Spreuke-Evangelie Q, pre-Pauliniese formules in Fil 2:8-11 en 1 Tim 3:16). Daarna kry ons by Paulus in die periode 54/55 n C kort opsommings van die 'opstanding' (nie 
resussitasie nie), sonder 'n verhaalraamwerk. Langer verhaalraamwerke met minimale besonderhede kom in die Markusevangelie voor en die is ongeveer $70 \mathrm{n} \mathrm{C}$ geskryf. Matteus, Lukas en Johannes, geskryf in die periode 85-95 n C, bevat detailverhale. By die kerkvader Ignatius kry ons in die 2 de eeu n $\mathrm{C}$ uitsprake oor die opstanding binne die raamwerk van die geloofsoortuiging met betrekking tot die Godheid van Jesus.

As ons nou sou vra watter implikasies die belydenis van die opstanding vir gelowiges vandag het, hiermee bedoel ek diegene onder ons wie se lewe nie in die alledangse gang van die lewe deur 'n 'alternatiewe staat van bewussyn' gekenmerk word nie, kan daar uiteraard verskillende antwoorde gegee word. Die belydenis van die opstanding van Jesus Christus wil volgens my sê dat om 'opnuut gebore te wees' (Joh 3:3) of om 'uit die dood na die lewe oor te gaan' (Joh 5:24), 'n eie opstanding veronderstel: ' $n$ nuwe bestaanswyse met eksistensiële momente waarin God die eindige in die oneindige, die tyd in die ewigheid, hierdie-tydse in sinvolle hede en toekoms, verander.

\subsection{Sy geboorte}

Wat die geboorte van Jesus betref, het die meerderheid van die lede van die Jesus Seminar in Oktober 1994 tot die historiese beslissing gekom dat hulle nie weet of Jesus van Nasaret verwek was terwyl sy ma Maria aan Josef verloof was nie. Histories gesien, is $96 \%$ van die seminaarlede seker daarvan dat Maria nie swanger geraak het sonder dat sy seksuele gemeenskap met 'n man gehad het nie. 50\% oordeel dat Josef moontlik die biologiese pa van Jesus was en $97 \%$ dat Maria wel sy biologiese ma was. In 'n afsonderlike stemming, oor spesifiek die gegewens in Matteus se geboorterekord van Jesus, is die meerderheid van die Jesus Seminar onseker of Jakob wel die pa van Josef was en daarom was die Jesus Seminar ook onseker of Jesus dus indirek van Dawidiese afkoms is. Persoonlik oordeel ek verder dat die uitdrukking 'seun van Dawid' in Romeine 1:3-4 en 2 Timoteus 2:8 geen verband het met die figuur 'Josef, seun van Jakob' nie. Beide hierdie verwysings is getuienis daarvan dat die na-Pase 'Christelike' geloofsgemeenskap Jesus van Nasaret as die Messias geëer het. 85\% van die Jesus Seminar meen wel dat Josef die naam was van die man wat Jesus as sy kind aangeneem het. $4 \%$ is van die oortuiging dat Maria as gevolg van of verkragting of verleiding deur 'n onbekende man geboorte gegee het aan Jesus. Hoewel daar nie besliste historiese gronde daarvoor bestaan nie, het $29 \%$ geoordeel dat dit wel moontlik kon wees dat Maria se swangerskap die gevolg was van of verkragting of verleiding. $23 \%$ het histories nie só beslis nie, terwyl $62 \%$ hieroor onseker was. Bykans almal, 99\% van die lede, is van cortuiging dat Matteus en Lukas se berigte dat Jesus deur die $(\mathrm{H})$ eilige (G)ees verwek is, nie 'historiese stelling' is nie, maar 'n 'teologiese'. Die meerderheid was ook onseker of Maria wel 'n maagd was by verwekking. Hulle meen dat sy waarskynlik wel swanger geraak het toe Herodes die Grote 'koning van die Jode' was. Die verwysing by Lukas dat daar tydens Jesus se geboorte 'n wêreldwye Romein- 
se sensus was, dat Jesus by geboorte in 'n krip neergelê was, dat herders die eerste was om erkenning aan sy geboorte te gee of, dat dit volgens Matteus eerder sterrekykers was, moet as onhistories verklaar word. Dit geld ook die verwysing in sowel Matteus as Lukas dat die geboorte in Betlehem plaasgevind het, die verwysing by Matteus dat kinders deur Herodes die Grote as gevolg van Jesus se geboorte vermoor is en dat Jesus na-sy geboorte deur sy ouers na Egipte geneem is, die verwysing by Lukas dat Johannes die Doper van priesterlike herkoms of ' $n$ nefie van Jesus was en dat Jesus as kind na die tempel geneem is waar Simeon en Anna vir Jesus sou gesien het. Al hierdie verwysings word sonder twyfel as onhistories geag. Heelwat ander stof in die briewe van Paulus aan die Galasiërs en aan die Korintiërs, in die Markusevangelie (en parailelle in die Matteus en Lukas) en in die bronne wat Eusebius gebruik het in verband met opmerkings oor lede van die familie van Jesus, kan in grade van waarskynlikheid as histories bestempel word.

As aktiewe lid van die Jesus Seminar stem ek, met enkele uitsonderings, saam met al bogenoemde historiese beslissings in verband met die geboorte van Jesus. Wat is die uitsonderings? Ek meen nie dat ons seker kan wees dat daar wel só 'n historiese figuur soos Josef was wat die swanger Maria as sy vrou geneem het en derhalwe die kind van Maria as sy eie aangeneem het nie. Histories gesien, is daar vier redes wat vir my skeptisisme in hierdie verband verantwoordelik is.

Die vroegste skriftelike bronne (Paulus, Q, Thomas en Markus) ken nie só 'n figuur met hierdie naam wat as Jesus se (aangenome) pa voorgestel is nie. Josef kom voor in daardie kontekste (duidelik gebaseer op 'n tradisie uit die gemeenskaplike leefwêreld) waar die Christelike gemeenskappe smeerveldtogte van die kant van veral die sinagoge moes teëstaan oor die 'skandelike' herkoms van Jesus, te wete Matteus en Johannes (en ' $n$ tradisie grondliggend aan Lukas). Die karaktertrekke van en gebeure rondom Josef, soos ons dit in die tradisie aantref wat deur Matteus oorgeneem is, vertoon opvallende ooreenkomste met tradisies oor die Ou-Testamentiese figur Josef soos wat dit onder andere neerslag gevind het in die pseudepigrawe, Josef en Aseneth, die Testament van Josef, die Testament van Simeon en die Testament van Dan (in die Testamente van die Twaalf Patriarge). In die geskrif Josef en Aseneth sien ons die beklemtoning van temas soos 'Josef, seun van Jakob'; die onverwagte 'goddelike' troue met 'n 'onreine'; Josef, die 'regverdige', die 'seun van God'; die detour na Egipte vanwaar, volgens Matteus na aanleiding van die profeteboek Hosea, God sy Seun roep. In die Testament van Josef, ten spyte van bepaalde Christelike interpolasies, is daar in die Armeniaanse weergawe verwysings na Josef se (apokaliptiese) droom en die maagd wat geboorte gee. In die Testament van Simeon [4:1] en in die Testament van Dan [5:1] word daar ook na Josef verwys as 'n 'regverdige en goeie man' wat die 'Gees van God' 
in hom het. Die waarskynlik Christelike interpolasie in die Testament van Josef hou verband met die 'lam van God' aan wie die maagd geboorte skenk en wat die 'sonde van die wêreld' wegneem. Die Josef-tradisie ontwikkel duidelik as 'n trajek (hand in hand met die anti-Christelike smeerveldtog in verband met Maria en die gepaardgaande ontwikkeling van die idee dat sy 'n 'rein' (sondelose) bevalling gehad het, na geboorte 'n maagd gebly het en selfs die vrug van 'n 'Goddelike geboorte' was. In die Nuwe Testament is daar van hierdie oortuiging geen teken nie; dit ontwikkel gedurende die tweede eeu in die Proto-Evangelie van Jakobus, en word voortgesit in Pseudo-Matteus en daarna in die Mariologie wat in die Rooms-Katolisisme ' $n$ hoogtepunt bereik.

Ek sou ook 'n kanttekening wou skryf by die onsekerheid van die meerderheid van die lede van die Jesus Seminar (62\%) of die geboorte van Jesus die gevolg was van verkragting of verleiding. Myns insiens kan ons hierdie hipotese met meer historiese beslistheid afwys. Ons het nie werklik implisiete toespelings daarop in die dokumente tot en met Justinus se eksplisiete hantering van hierdie Joodse beskuldiging nie. Die geloofwaardigheid van hierdie getuienis kan dus nie gebou word op die prinsiep van meervoudige onafhanklike getuienis nie. Dit is gebaseer op die sogenoemde 'Yeshu ben Pantera'-tradisies in die Talmoed en die Middeleeuse Toledot-tradisies wat van mekaar afhanklik en uiters tendensieus is.

Dit neem egter nie weg dat daar histories betoog kan word dat Jesus se herkoms wel as 'illegitiem' volgens die maatstawwe van die tweede tempelperiode gesien moet word nie. Ek oordeel dat dit die agtergrond van sowel Matteus as Johannes se apologie

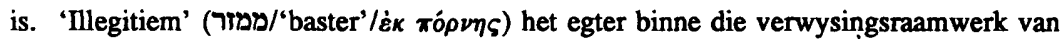
die huwelikstrategie van die tweede tempelperiode se reinheidsideologie nie slegs die konnotasie dat jou ma willens en wetens ' $n$ 'slegte vrou' sou wees nie. In die familiale struktuur van Israel (en Umwelt) het 'n vrou wat nie bevoorreg was om in die beskermingskring van haar man (of substituut) te staan nie, dikwels die etiket 'hoer' ontvang. 'n Kind van só 'n vrou (gewoonlik die eersgeborene) is geag as 'gebore uit ontug'.

Dikwels het hierdie uitdrukking betrekking gehad op 'gemengde huwelike', dit wil sê wanneer 'n 'seun/dogter van Abraham met iemand 'buite die verbond' sou trou. Sedert die na-eksiliese huwelikshervormingsmaatreëls (kyk Neh 9-10; Esra 9-10), beslis ook gedurende die eerste eeu, is daar op grond van 'priesterlike' reinheidskodes aangedring dat Israelitiese mans sulke vrouens moet skei. Die gevolg was 'vaderloosheid', ofte wel 'illegitimiteit'. 'Vaderlose' mans (seuns ouer as twintig) mag vanweē hierdie 'permanente sonde' van hulle nie in die tempel gekom het nie (kyk Deut 23:3) en ook nie met 'n mede-'volbloed' Israeliet trou nie (kyk [Babiloniese] Yebamot 78b). 'Illegitimiteit' kan natuurlik ook verwys na 'n geboorte as gevolg van onsedelikeid, ontering, 
bloedskande of verleiding. In Thomas 105 vind ons 'n spreuk van Jesus wat moontlik daarop dui dat sy 'sonde' (kyk Thomas 104) verband hou met die feit dat iemand wat nie weet wie sy pa (of $\mathrm{ma}$ ) is nie (met ander woorde iemand wat geen 'identiteit' gehad het nie, omdat hy nie 'n 'seun van Abraham' is nie) 'n 'kind van 'n hoer' genoem sal word.

Drie ander verwysings na hierdie selfde tema word in onafhanklike dokumente aangetref wat bevestig dat die tradisie met betrekking tot Jesus se 'illegitimiteit' histories baie ernstig opgeneem moet word. Hierdie tradisie word onafhanklik betuig in die vroegste stratum van dokumente (Thomasevangelie, geskryf ongeveer $50 \mathrm{n} \mathrm{C}$ ), in die tweede stratum (Markusevangelie, geskryf ongeveer $70 \mathrm{n} \mathrm{C}$ ), in die derde stratum (in Lukas en Matteus, geskryf ongeveer 80-90 n C - in tradisies onafhanklik van Markus) asook in die laaste stratum (Johannesevangelie, geskryf ongeveer einde eerste eeu). In Markus 6:3 (teen die agtergrond van Jesus se verwerping deur sy familie in Nasaret) word daar nie na Jesus verwys as die 'seun van Josef' nie, maar as die 'seun van Maria'. Laasgenoemde uitdrukking is ' $n$ aanduiding van iemand sonder identiteit, 'n 'illegitieme' persoon sonder 'n pa wat aan so-iemand geloofwardigheid kon verleen.

Die tweede verwysing word in Matteus 27:64 gevind. Ek interpreteer die frase 'die laaste dwaling is erger as die eerste' in hierdie vers as 'n verwysing na die smeerveldtog deur die opponente van die gemeente van Matteus: volgens die smeerveldtog is die legende in verband met die opstanding van Jesus die 'laaste kettery' wat 'n 'erger kettery' is as die 'eerste'. Laasgenoemde verwys myns insiens na die oortuiging dat Jesus, ten spyte van sy 'vaderloosheid', deur God as 'seun van Abraham'/'seun van God' gelegitimeer is vanweë die Josef-tradisie (gekombineer met die Moses-tradisie volgens Pseudo-Filo) dat 'n engel in 'n droom Josef (Amram) opdrag gegee het om met Maria (Jogebed) te trou wat swanger was deur die toedoen van die (H)eilige (G)ees.

Die derde verwysing kom in Johannes 19:9 voor. In hierdie gedeelte is daar die vraag van Pilatus (teen die agtergrond van die beskuldiging dat Jesus 'koning van die Jode' sou wees) aan Jesus: 'waar kom jy vandaan?' en Jesus se stilswye. Volgens die Rabbynse literatuur (kyk Qiddusin 4:2) moet iemand swyg wanneer hy gekonfronteer word oor sy herkoms en hy nie weet wie sy pa is nie. (Die verwysing in Qiddusin 4:2 het betrekking op 'straatkinders' wie se ouers onbekend is; vergelykende historiese navorsing het getoon dat 'basters', selfs in opeenvolgende geslagte, 'n sub-gemeenskap in onder andere die Mediterreense wêreld ter wille van 'oorlewing' saam met ander sosio-religieuse 'onreines' as gevolg van ostrasisme gevorm het.)

Ek lees met ander woorde Matteus 1:1-17; 1:18-25; $27: 64$ sowel as Johannes 1:45; $6: 42 ; 8: 41 ; 19: 9$ (insluitende tradisies soos dié in die tweede-eeuse Handelinge van Pilatus 2:3), as 'verdedigende narratiewe kommentaar'. Ook die apologetiese tendens met betrekking tot Jesus se 'doop tot vergifnis van sonde' deur Johannes die Doper 
(Matt 3:14v; vgl die Evangelie van die Nasareërs, aangehaal deur Hiëronimus in Contra Pelagius [3.2]; die Evangelie van die Ebioniete, aangehaal deur Epifanius in Ketterye [10.13.7-8]; Josefus, $A J$ 18.117), veral soos dit in die 'sonder sonde'-motief in die brief aan die Hebreërs (4:15) vorendag kom as deel van 'n verleentheid met betrekking tot die aard van Jesus se geboorte wat iemand soos Paulus (Gal 4:4) nie gedeel het nie!

Net soos die belydenis van Jesus se opstanding reeds vroeg aan die begin van die tweede eeu n $\mathbf{C}$ deur die kerkvader van Antiogië, Ignatius, ingespan is om die belydenis 'Jesus is God' te onderbou, het dieselfde met betrekking tot die geboorte van Jesus gebeur. Maar, net soos in die geval van die geloof met betrekking tot die opstanding, moet ons daarteen waak om dit wat latere getuies gesê het, in dit wat vroeër gesê is, in te lees.

Ek het reeds daarop gewys dat die vroegste getuies in die Nuwe Testament, Paulus en Markus, nie 'n maagdelike geboorte van Jesus ken nie. Wat die Nuwe Testament betref, het alleen die Matteus- en die Lukasevangelie die geboorte van Jesus in hulle vertellings oor Jesus opgeneem. Ons het gesien dat Ignatius die geboortevertelling in die Matteusevangelie eksplisiet as 'n maagdelike geboorte geïnterpreteer het. Sy motief was om die gnostiese dwaling te weerle dat God nie met verwerplike mensheid verenig nie. In die tweede eeu bely onder andere die kerkvader Origenes ook die maagdelike geboorte. Dit het hy gedoen teen die agtergrond van onaanvaarbare oortuigings dat die familie van Jesus na bewering aanspraak daarop sou maak dat Jesus 'n Jood vir slegs Jode sou wees. Met die belydenis van Jesus se verwekking deur die Vader wou Origenes beklemtoon dat Jesus betekenis het vir die ganse mensdom, want God kan nie binne die grense van die Jodedom ingeperk word nie.

Terselfdertyd is daar met die belydenis van die maagdelike geboorte wal gegooi teen ' $\mathrm{n}$ toenemende afwykende gedagte dat God nie woning wil maak in nietige mensheid nie. Juis daarom het die belydenis van die maagdelike geboorte gedurende die tweede eeu 'n voorwerp van bespotting vir die Griekse filosoof, Celsus, geword dat Christene hulleself sou aanmatig deur te beweer dat God se Seun vanuit 'n nederige kleinboerderygemeenskap soos Nasaret kan kom. Celsus maak beswaar daarteen dat die nederige Jesus op dieselfde vlak as die helde in die Griekse mitologie geplaas word. Spore van 'n reaksie op 'n soortgelyke verleentheid kan reeds in die Evangelie van Johannes gesien word.

Net soos Paulus die skande van die kruisdood van Jesus nie wou ontken nie, maar dit as 'God se wysheid' bestempel het, is die skande van Jesus se herkoms ook nie deur Matteus ontken nie. In sowel sy weergawe van die geboorterekord van Jesus as van die Josef-tradisie, toon hy dat God 'kinders van Abraham' ook vanuit 'onheilige saad' kan skep (vgl ook Matt 3:9). Tog gee Matteus se apologetiese opmerkings blyke daarvan 
dat hy ook insien dat Jesus se 'vaderloosheid' en sy doop tot vergifnis van sonde deur Johannes die Doper sy gemeente voor hulle sinagogale opponente weerloos sal maak en in verleentheid sal dompel. Matteus sluit daarom by die profeet Miga aan wat praat van die geboorte van 'n 'koningskind' in die geringe Betlehem en nie in die magtige Jerusalem nie, maar 'n nederigheid wat as gevolg van God se ingrype gekanselleer word. Dit is hierdie 'koningskind', in aansluiting by die profeet Jesaja [LXX 8:8], wat God-by-ons is, en nie die Idumeër, Herodes die Grote, wat deur die keiser van Rome as 'koning van die Jode' verklaar is nie.

Matteus bou veral voort op temas wat bekend was in die Joods-Griekse literatuur van die eerste eeu n C (bv Josefus se Antiquitates en Pseudo-Filo se Liber Antiquitatum Biblicarum). Hierdie temas hou verband met oortuigings dat Moses se geboorte van Goddelike ingrype getuig. In sekere van hierdie dokumente is daar ten opsigte van Moses selfs sprake van 'n 'Goddelike geboorte' (Eks Rabbah 1:20; b. Sota 12a; b. Baba Batra 120a) en dat, na aanleiding van onderskeidelik Eksodus 7:1 en Eksodus 4:16, Moses 'God' vir Farao en vir die volk ( $\mathrm{d}$ v Aäron) bemiddel het. In die Matteusevangelie funksioneer Moses op ' $n$ baie duidelike wyse as ' $n$ tipe van Jesus.

Ons moet onthou dat die Judaïsme die verskynsel van buitengewone verwekkings geken het. So word daar byvoorbeeld berig gegee van engele wat menslike wesens bevrug (kyk 1 Henog 6-7; 1QapGen ['Genesis Apocryphon, Qumran 1'] 2; Test Sal 5:3; Prot Jak 14:1). Daar is selfs aan die einde van sommige manuskripte van 2 Henog [71] die legende van die wonderbaarlike verwekking en geboorte van Melgisedek. Van Sara word selfs gesê (b. Yebamot 64a-b) dat sy 'kinderloos' is, 'sy het nie eens 'n baarmoeder gehad nie'! Ek is daarvan oortuig dat die Griekse woord 'maagd' (in Grieks: $\pi \alpha \rho \theta \varepsilon ́ v o \varsigma$ ) in die bepaalde Griekse weergawe van Jesaja 7:14 wat deur Matteus aangehaal word, nie die Leitmotif vir die sitaat is nie, maar die Griekse woord 'E $\mu \mu \alpha \nu$ ovं $\lambda$, 'God-by-ons', ter wille van die gemelde Moses-tipologie. Indien Matteus die woord 'maagd' ( $\pi \alpha \rho \theta \dot{v} \nu \circ$ ) wel intensioneel in die oog gehad het, sou sy intensie myns insiens nie veel anders gewees het as dit wat in die (haggadiese) Moses-paasgeskrif (b. Baba Batra 120a) met betrekking tot Jogebed, die ma van Moses, gesê is nie: 'Soos geskrywe is, "En 'n man vanuit die huis van Levi [Amram] het gegaan, en hy het 'n dogter van Levi [Jogebed] as vrou gevat; hoe kan sy 'dogter' genoem word as sy honderd en twintig jaar oud was?" ... "Die les is dat die tekens van maagdelikheid in haar herstel is ...."' Hiermee word aan Moses 'n 'maagdelike geboorte' toegeken.

Hoe moet ons die oortuiging van $99 \%$ van die Jesus Seminar dat Matteus en Lukas se berigte dat Jesus deur die (H)eilige (G)ees verwek is, nie op 'n 'historiese stelling' neerkom nie, maar op 'n 'teologiese', eksegeties vertolk? Die gebruik van die uit-

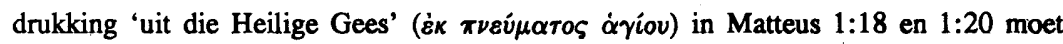


teen die agtergrond van die triadiese formule in Matteus 28:19 verstaan word. Hierdie formule is 'n midrash-tipe (apokaliptiese) toespeling (met woordelikse ooreenkomste) op die trias in Daniël [LXX] 7:13-14. Josefus (Ant 4.326) het ook Moses se 'finale vertrek' in terme van Daniël 7 geïnterpreteer. In Matteus se 'na-Pase kroningsteofanie-sendingopdrag' word die 'Menseseun' in dieselfde asem as die 'Oue van Dae' en die 'Engele' genoem en word daar deur middel van die uitdrukking 'met julle' ( $\mu \varepsilon \theta$ ' $\dot{\boldsymbol{\nu}} \mu \hat{\omega} \nu$ - vs 20) teruggegryp na die geboorte van Jesus. Die (H)eilige (G)ees(te) word in talle voorbeelde van dieselfde triadiese formule (nie altyd in dieselfde volgorde van die lede nie) in sowel die Nuwe Testament as Ou-Testamentiese pseudepigrawe met 'heilige engele' uitgeruil (kyk bv Mark 8:38; Mark 13:32; Matt 25:31-43; Matt 13:3643; Luk 12:8-9; 1 Tess 4:13-18; 2 Tess 1:5-10; Opb 1:4-7; 5:6-7; 11:15-18).

Raymond Brown het (na aanleiding van die navorsing van $\mathbf{R}$ Fuller) tereg opgemerk dat die Heilige Gees se relasie tot Jesus se Godseunskap eers met betrekking tot die opstanding geartikuleer is (kyk ook Rom 1:3-4), toe met betrekking tot sy doop, en daarna met betrekking tot sy geboorte.

In die Lukasevangelie word die geboorte van Jesus, verwek deur die Heilige Gees, gestel teenoor die geboorte van die keiser van Rome, Augustus. Hierdie keiser, 'n aangenome seun van Julius Caesar, se eie herkoms is teruggevoer na 'n goddelike geboorte volgens die godeverhale wat kom uit die legendes van die Julius-familie. Augustus het ook sy eie verjaarsdag as 'n 'evangelie' beskryf en hy het homself as 'n god verklaar wat vereer moet word as die 'redder van die wêreld'. In die Lukasevangelie word Jesus se geboorte en die betekenis daarvan egter as sodanig beskryf.

Wat nêrens in die Nuwe Testament gebeur nie, het by Ignatius plaasgevind toe hy sy verstaan van die maagdelike geboorte van Jesus Christus in verband gebring het met die gedagte van pre-eksistensie en inkarnasie. Hierdie gedagte is wel by Paulus en in die Johannesevangelie aanwesig, maar nie in of Lukas se vertelling oor Jesus se maagdelike geboorte of Matteus se vertelling oor Jesus se goddelike geboorte nie. Die ontwikkeling by Ignatius, waarvan daar spore in die Johannesevangelie is, het antidoketiese motiewe, sowel as om die sondeloosheid van die Messias te beklemtoon. Die feit dat veral Thomas van Aquinas gedurende die Middeleeue die virtus van die Heilige Gees (in onderskeid van die substantia van die Vader) in die verwekking van die Messias beklemtoon het, is ' $n$ aảnduiding daarvan dat die Triniteitsleer die verwysingsraamwerk begin vorm het waarbinne die maagdelike geboorte van Jesus geïnterpreteer is. Laasgenoemde ontwikkeling vorm die belangrikste agtergrond van die geloofsoortuiging met betrekking tot die belydenis van die maagdelike geboorte soos dit in die reformatoriese belydeniskrifte tot uitdrukking gebring is. Met die 'leer' wat in hierdie geloofsoortuiging uitgedruk is, is ook ek vandag konform. 
Hoewel ons nie al hierdie aspekte meteen reeds in die vroegste getuies, soos Paulus en Markus, kan inlees nie en ook nie hierdie getuies kan laat sê wat eers later bely is nie, kan ek nie anders as om instemming te toon met die saak wat ten grondslag van die belydenis van die maagdelike geboorte lê nie. Die vraag of hierdie belydenis steeds deel van ons belydende lewe vandag moet wees, hang vir my nie daarvan af of daar 'bewyse' daarvoor in die Heilige Skrif gevind kan word of nie. Die Heilige Skrif is immers nie in die eerste plek bedoel om te dien as 'n handboek van 'teksbewyse' van onveranderlike leerstukke nie. Die Heilige Skrif is die bron van die lewende stem van God wat in en deur die kerk verkondig word. Om die geloofsoortuiging wat in die belydenis van die maagdelike geboorte uitgedruk is, steeds vandag te bely, hang ook nie daarvan af of dit vir moderne mense vandag met die verstand bewysbaar is of nie. Die vraag is of die 'hart' van hierdie belydenis deel van die evangelie is of nie. En dit, meen ek, is wel die geval: God het en maak nog steeds woning by nietige en hulpelose mense wat weet hoe afhanklik hulle van God is; $\mathrm{Hy}$ verhoog die nederige en verneder die hoogmoedige; Hy het die wêreld oneindig lief; Hy tref geen onderskeid tussen persone en groepe nie; Hy maak Homself vir ons in Jesus, vir ons Christus en Here, bekend.

\section{Geraadpleegde literatuur}

Allison, D C 1993. The new Moses: A Matthean typology. Minneapolis: Fortress.

Borg, M J 1994. Jesus in contemporary scholarship. Valley Forge: Trinity Press International.

1995. Als met nieuwe ogen: De historische Jezus en waar het op aan komt in het geloof van vandaag. Zoetermeer: Meinema.

Brown, R E 1973. The virginal conception \& bodily resurrection of Jesus. New York: Paulist Press.

1979. The birth of the Messiah: A commentary on the infancy narratives of Matthew and Luke. First Image edition. New York: Doubleday.

Bultmann, R [1960] 1965a. Das Verhältnis der urchristlichen Christusbotschaft zum historischen Jesus. Vierte Auflage. Heidelberg: Carl Winter, Universitätsverlag. (Sitzungsberichte der Heidelberger Akademie der Wissenschaften Philosophischhistorische Klasse 3.)

Charlesworth, J H (ed) 1985. The Old Testament Pseudepigrapha, Volume 2: Expansions of the 'Old Testament' and legends, wisdom and philosophical literature, prayers, psalms, and odes, fragments of lost Judeo-Hellenistic works. Garden City, NY: Doubleday.

Crossan, J D 1986. From Moses to Jesus: Parallel themes. Bible Review 2/2, 18-27. 1991. The historical Jesus: The life of a Mediterranean Jewish peasant. San Francisco: Harper. 
Crossan, J D 1994a. The infancy and youth of the Messiah, in Shanks, H (ed), The search for Jesus: Modern scholarship looks at the Gospels, 59-81. Washington, DC: Biblical Archaeological Society.

- 1994b. The historical Jesus: A revolutionary biography. San Francisco: Harper.

Davies, S L 1995. Jesus the healer: Possession, trance, and the origins of Christianity. New York: The Continuum Publishing Company.

Engelbrecht, J 1994. Skrifgetrouheid en Jesusfilms. Religie \& Teologie 1/3, 292-300. 1995. Jesus in films: A century observed. Scriptura 52, 11-25.

Funk, R W 1990. Criteria for determining the authentic sayings of Jesus. Fourth $R$ $3 / 6,8-10$.

1994. The resurrection of Jesus: Reports and stories. The Fourth $R$ 7/4, 3-16. 1995. Bookshelf: The resurrection of Jesus. The Fourth $R$ 8/1, 3-16.

Funk, R W \& Hoover, R W (eds) 1993. The Five Gospels: The search for the authentic words of Jesus. New York: Macmillan Publishing Company.

Hamilton, W 1994. A quest for the post-historical Jesus. New York: Continuum.

Johnson, L T 1995. The search for (the wrong) Jesus. Bible Review, December 1995, pp 20-44.

Käsemann, E 1954. Das Problem des historischen Jesus. ZThK 51, 125-153.

K̉lauck, H-J 1996. Die religiose Umwelt des Urchristentums, II: Herrscher- und Kaiserkult, Philosophie, Gnosis. Stuttgart: Kohlhammer. (Kohlhammer Studienbücher Theologie.)

Kloppenborg, J S 1993. The Sayings Gospel Q: Recent opinion on the people behind the document. Currents in Research: Biblical Studies 1, 9-34.

Lüdemann, G 1994. Die Auferstehung Jesu: Historie, Erfahrung, Theologie. Stuttgart: Radius-Verlag.

Machovec, M [1972] 1977. A Marxist looks at Jesus, with an introduction by P Hebblethwaite. A translation of Jesus fur Atheisten. London: Darton, Longman \& Todd.

Mack, B L 1993. The lost gospel: The book $Q$ and Christian origins. San Francisco: Harper \& Row.

Malina, B J 1981. The New Testament world: Insights from cultural anthropology. Loisville: John Knox Press.

Meeks, W A 1970. Moses as God and King, in Neusner, J (ed), Religions in antiquity: Essays in memory of Erwin Ramsdell Goodenough, 354-371. Leiden: Brill.

Meier, J P 1991. A marginal Jew: Rethinking the historical Jesus, Volume one: The roots of the problem and the person. New York: Doubleday.

- 1994. A marginal Jew: Rethinking the historical Jesus, Volume two: Mentor, message, and miracles. New York: Doubleday. 
Miller, R J (ed) 1992. The complete gospels: Annotated scholars version. Sonoma: Polebridge.

Patterson, S J 1993. The Gospel of Thomas and Jesus. Sonoma, CA: Polebridge. (Foundations \& Facets Reference Series.)

Pilch, J 1995. Insights and models from medical anthropology for understanding the healing activity of the historical Jesus. HTS 51/2, 314-337.

Riley, G J 1994. The Gospel of Thomas in recent scholarship. Currents in Research: Biblical Studies 2, 227-252.

Sanders, E P 1993. The historical figure of Jesus. New York: Allen Lane - Penguin.

Schaberg, J 1982. The Father, the Son and the Holy Spirit: The triadic phrase in Matthew 28:19b. Chico, CA: Scholars Press.

1987. The illegitimacy of Jesus: A feminist theological interpretation of the infancy narratives. San Francisco: Harper \& Row.

- 1994. The cancelled father: Historicity and the NT infancy narratives. Paper presented at the Westar Institute's Jesus Seminar, Santa Rosa (CA), October 1994.

Scott, Bernard B [1989] 1990. Hear then the parable: A commentary on the parables of Jesus. Minneapolis: Fortress.

- 1994. From Reimarus to Crossan: Stages in a Quest. Currents in Research: Biblical Studies 2, 253-280.

Sheehan, T 1995. The resurrection: An obstacle to faith? The Fourth $R$ 8/2, 3-9.

Stegemann, E W \& Stegemann, W 1995. Urchristliche Sozialgeschichte: Die Anfänge im Judentum und die Christusgemeinden. Stuttgart: Kohlhammer.

Tatum, W B 1994. John the Baptist and Jesus: A report of the Jesus Seminar. Sonoma, CA: Polebridge.

Time International 1996. Jesus Christ, Superstar. April 29, p 6.

Van Aarde, A G 1994a. Tracking the pathways opened by Willem Vorster in historical Jesus research. Neotestamentica 28, 235-251.

- 1994b. The epistemic status of the New Testament and the emancipatory living of the historical Jesus in engaged hermeneutics. Neotestamentica 28/2, 575-596.

1995a. Die historiese Jesus, die Jesus-beweging en die vorming van die kerk. HTS 51/3, 623-644.

- 1995b. The 'third quest' for the historical Jesus - where should it begin: With Jesus' relationship to the Baptiser, or with the nativity traditions? Neotestamentica 29/2, 325-356.

[1996a]. Kultuurkritiek, die historiese Jesus en eerste-eeuse kulturele wysheid. HTS 52/4. [Beplan om te verskyn in November 1996.]

- 1996b. Social identity, status envy and the historical Jesus' Abba. Paper presented at the International Meeting of the Society of Biblical Literature, Dublin, July 24, 1996. 
Van Aarde, A G 1996c. The relevance of historical Jesus research for New Testament scholarship, faith and society. Jesus Seminar Papers, Santa Rosa, February 1996, 55-57.

Van Biema, D 1996. The gospel truth? Time International April 8, pp 40-47.

Weber, M 1949. Max Weber on the methodology of the social sciences, translated and edited by E A Shils and H A Finch. With a foreword by E A Shils. Glencoe, IL: The Free Press.

Westar Institute [1996]. Jesus Seminar Phase 2: Deeds votes, Fall 91-Fall 95.

Witherington, B 1994. Jesus the sage: The pilgrimage of wisdom. Minneapolis: Fortress.

1995. The Jesus quest: The third search for the Jew of Nazareth. Downers, Il: InterVarsity Press. 